\title{
Dr. Manuel Justo Domínguez Quintanar, founder of rational childcare and creator of technical pediatrics in Mexico
}

\author{
Manuel A. Baeza-Bacab
}

Faculty of Medicine, Universidad Autónoma de Yucatán; Academia Nacional de Medicina de México (Pediatrics); Academia Mexicana de Cirugía (Pediatrics); Academia Mexicana de Pediatría, Mérida, Yucatán, Mexico

\begin{abstract}
This paper presents some biographical notes, both personal and professional, for Dr. Manuel Justo Dominguez Quintanar; a native of Queretaro, who over 80 years lived firsthand the historical stages in which Mexico turned into an independent country: from the First Federal Republic to the Porfiriato. He had an active participation in them all; either as a doctor, a teacher, administrator or politician. He was renowned for his charity work, especially in the Foundling House (The Cradle), which made him years later, to be considered as the founder of rational childcare and the creator of technical pediatrics in Mexico.
\end{abstract}

KEY WORDS: Pediatrics. History. Children. Childcare.

\section{Introduction}

According to Dr. Alfonso G. Alarcón, in Mexico, as in other countries, childcare has been a child of obstetrics and pediatrics a child of childcare; therefore, the first childcare specialists and pediatricians were male midwives, who were forced by the presence of the newborn to be the protectors of a healthy childhood and, necessarily, doctors of the sick child'1. However, claims Dr. Alarcón, it cannot be denied that in Mexico childcare existed before the genuinely scientific era of medical art. There is the Foundling House (La Cuna), founded by Don Antonio Lorenzana y Buitrón, archbishop of Mexico, by the end of the $18^{\text {th }}$ century, which in spite of having been created without special experience or culture, always showed concern to preserve human nutrition for the infants. However, the founder of rational childcare was Dr. Manuel Domínguez, who in 1884, a little more than 130 years ago, devoted his attention and La Cuna services almost exclusively to infants'. The present work relates some aspects of Dr. Manuel J. Domínguez Quintanar personal and professional life, who was a physician, politician, administrator and teacher, but especially, Mexican children benefactor.

\section{Dr. Manuel J. Domínguez Quintanar origins}

He was born in the city of Queretaro on August 6, 1830. His parents were General Juan B. Domínguez and Mrs. María Ignacia Quintanar Delgado. He was baptized at the Santa Ana parish by Presbyter Manuel Borja González, who gave him the names Manuel Justo, with his godfather being the vice-governor of the State of Querétaro, Don Nicolás Berasaluce. He spent his first years in San Juan del Río, Querétaro, where her mother had some haciendas. When his education started, he was sent to Querétaro and trusted to Father Borja's guardianship. At 7 years of age, he was enrolled in a small school, located at the la Verónica Street, run by the Bustillo ladies, where teaching included the use of "the pointer" and "St. Michael's Syllabary". His primary education was under the direction of virtuous professor Agustin Guevara, having Manuel Carmona y Valle as classmate.

\section{Correspondence:}

Manuel A. Baeza-Bacab

Calle 54 \# 365-112 por Av. Pérez Ponce

C.P. 9700, Mérida, Yuc., México

E-mail: manuel.baeza@correo.uady.mx
Date of reception: 20-06-2016

Date of acceptance: 20-06-2016

DOI://dx.doi.org/10.24875/GMM.M18000101
Gac Med Mex. 2017;153:844-853

Contents available at PubMed www.gacetamedicademexico.com 
There, as Dr. Domínguez comments, they learned reading, writing, Father Ripalda's Catechism and the basic rules of arithmetic quite well ${ }^{2,3}$. It was then when a deep friendship with Carmona y Valle, which was to be lifelong, was born. Thus remembered Manuel Domínguez in a speech delivered in a posthumous tribute paid to his friend: "I have tried, gentlemen, a course canvas where I sketch the life of someone who was almost a brother to me. In our dear elementary school, I was once seen by most children with repulsion, with scorn or fear, because large plaques of my epidermis were detaching owing to a scarlet fever I had suffered from. None of my little comrades wanted to occupy a seat adjacent to mine, and in the hours of recess I was excluded from games and was left isolated in a corner of the schoolyard, where I watched my cruel small schoolmates with teary eyes, devoted to the joyful recreation activities of an age of happiness. However, one of them, Manuel Carmona, was selfless enough as to approach me and, overcoming the natural repugnance I surely caused, he used to talk to me with affectionate interest and used to present me with his tiny clay figures in order to attenuate my obscure melancholy".

\section{Medical studies in Mexico City}

At 12 years of age, young Domínguez travelled to the capital city to continue his education and was admitted to the Colegio de San Juan de Letrán, first as a grant holder and later as external student. Dr. José $\mathrm{M}^{\mathrm{a}}$ Iturralde was dean of the establishment, and under his direction he studied two years of Latinity with Mr. Asain, BA, first year of philosophy with Mr. Calleja, BA, and the second with Miguel C. Alatriste, the brave leader of democracy, who was to be executed many years later close to Puebla²,3.

In those days, according to the General Curriculum decree proposed by president López de Santana on August 18, 1843, high school education was 6 years' long in order to be able to study medicine, and it was possible to complete the first 4 years in any of the capital city high schools (San Gregorio, San Hipólito or San Juan de Letrán), where Dr. Domínguez carried them out. After that period, in 1847, he enrolled as a student in the School of Medicine, which that year has moved to Colegio de San Juan de Letrán, where he studied the last 2 years of high school education, which included physics and medical chemistry, imparted by venerable wise men Ladislao de la Pascua and Leopoldo Río de la Loza, respectively. That year, his father passed, and he had to continue his education restricted to his own resources s.5-7. $^{3,5}$

In those days, the director of the school was Dr. José Ignacio Durán, and according to the above mentioned decree, the undergraduate program was 5 years long, and it should be highlighted that the fifth year included the course Obstetrics, diseases of women giving birth and newborn children, which shows an early interest on children's health ${ }^{8}$. In 1849, he moved to the old San Hipólito Hospital, where practical medicine courses were taken. Dr. Domínguez remembered with sadness that, in those days, General Santa Anna administration turned San Hipólito Hospital into headquarters for his army, leaving the students without a place where to receive their medical training. "Students and teachers, we protested as a group against the huge plunder; however, justice veiled her divine countenance, and we wandered, as Brahma's outcasts, from one place to another, turned down everywhere, and with no more shelter to continue with our school activities than the homes of our professors. The crisis concluded with the purchase made by our selfless teachers of the building of the Court of the Holy Office of the Inquisition, which once was a den of sinister inquisitions and that today is a source of intellectual light, and under the venerable roof of this building, we reached the finish line of our medical education"4. After having been an intern at the San Andrés Hospital, he took the Medicine, Surgery and Obstetrics exam on December 19, 1854, and was unanimously approved by the qualifying jury, comprised by professors Ignacio Herazo, José Espejo, Manuel Robredo, Ignacio Torres and Anastasio Peñuñuri. Then, as a degree holder, he headed to the city of León, Guanajuato, but he didn't find any job and, after some days, he moved to San Juan del Río, usual place of residence of his mother, who had already remarried to a spirited and talented man, Dr. José G. Perusquía. The sweet motherly love, the friendly manifestations of a large part of the neighborhood, the weather and childhood memories rooted him in that soil. Thus it happened, and even when later his stepfather decided to set his residence in the metropolis, he continued under that sky, absorbing the local customers and, as it usually occurs in all small villages, his permanence and this work drove the neighborhood to request from the State governor to assign him as district prefect in $1859^{5,6,10}$.

\section{A liberal physician among imperialists}

Political events forced him to migrate to the capital city, where he remained until Maximilian imperial 
government establishment. Supportive of the new order of things, he was appointed as San Juan del Río district prefect; therefore, on August 15, 1864, he was in charge of receiving Emperor Maximilian on his way to Querétaro. Prefect Domínguez declared the day as national holyday, had prisoners carrying out light sentences freed and organized different celebrations for such a magnificent occasion; even, since Maximilian came without Charlotte, the Emperor's partner for the Ball of Honor was Paz Domínguez, the prefect's sister. Dr. Domínguez was then a young doctor who had moved from the liberal party to the imperial party, and he was quite popular owing to his humanitarian ideas ${ }^{8}$. On that post, he was very helpful to the neighbors of the city, since he managed to normalize public services functioning, restore order and guarantee the interests of the community, which were services that were recognized by the imperial government by awarding him with the Knight of the Guadalupe Imperial Order medal on August 16, 18649. On February 10, 1866, he married Miss Adelaida Girón Rico in San Juan del Río, with the sorrow in those days of losing his mother. In his marriage, he had 7 children, out of whom died very young. However, San Juan del Río registry data only mention 6: Manuel Ignacio, Salvador, Gustavo, Felipe, Adelaida and Octavio ${ }^{2,3,7}$.

After barely 3 years, with his government disorganized, Maximiliano passed again by beautiful San Juan del Río on his way to Querétaro, in a journey that was to have no return. Dr. Domínguez had to follow his leader's luck and joined him on the way to Querétaro, where they entered to on February 19, 1867. Soon after, the republican forces arrived and established the famous Querétaro siege, which concluded with the occupation of the place and Emperor Maximilian execution. In the first days of the memorable siege, generals Leonardo Márquez and Tomás Mejía came to Dr. Domínguez lodging to ask him, on behalf of the Emperor, to accept the both delicate and dangerous Querétaro Imperial prefect post. The commitment was such, that he accepted and at the end of the drama he was made prisoner together with the other defeated imperialists. In spite of his official position, during the siege he had the courage and audacity to silently challenge the imperialists, he showed his human sensitivity, he had solidary actions for the population by making their shortages less excruciating and protecting liberal prisoners, sparing them punishments and revenge. For all this, notable people of the city, especially triumphant liberal party affiliates, in recognition of the many services he had provided them, interceded for Dr. Domínguez with general in chief Mariano Escobedo, who agreed and ordered for the prisoner to be set free, without further obligation but to deliver the San Juan del Río prefecture files to the person that had been assigned to that post. The next day, he took off to carry out his orders, which was possible thanks to the generosity of Dr. Vicente Licea, a Queretan gynecologist, who handed him an ounce of gold as a friendly loan. After a few days in San Juan, his friends in Querétaro warned him that the order had arrived from San Luis Potosí for generals Márquez and Mejía, one mister Pasos, payer of the forces, and prefect Domínguez to be executed; they also urged him not to incur the quixotism of attending, because they wouldn't be able to answer for the result, and since he had not given his word to return in ulterior emergencies, he left the city and wandered for over 2 months dressed up as a rancher until he was able to enter the metropolis, which was already occupied by Mr. Juárez and his government, and he went into hiding at family Riba y Echeverria's home $e^{2,3,7,10}$.

\section{His beginnings as a doctor in the restored republic}

It didn't take too long for Don Antonio Riba to bring his hiding friend before Minister Sebastián Lerdo de Tejada, who did not send him to the improvised prison for political prisoners at La Enseñanza, but gave him the city for prison for 2 years. Under these conditions, he had his wife and the only child they had in those days brought from San Juan del Río, and they established in a humble house at la Santísima street, located towards the east of the main square and behind the City Hall, hoping that the products of his practice were sufficient to cover the expenses of the modest household. However, the few clients that attended the office were poor and did not produce enough, which forced the couple to a new separation: the family went back to San Juan del Río and Dr. Domínguez lodged in a room of the Betlemitas baths that was handed over by his good friend Ruperto Barrera, manager of the business, who also formed a group of customers for him, making for some of his friends to form a "pool" whereby, for a monthly fee, they would have right to the medical services lent by Dr. Domínguez ${ }^{2,3}$.

In 1870 he got the post of prefect of studies at the National School of Medicine, which paid 500 pesos annually, and which enabled the couple to be reunited again. It should be noted that, in those days, the 
school was already located at the Inquisition Palace, and that the housing for interns was in the corridors of the second courtyard. There, he met the poet Manuel Acuña, then a medical student, with whom he cultivated a fraternal friendship that is reflected on the sonnet Acuña wrote to his teacher:

To my dear friend and teacher Manuel Domínguez ${ }^{11}$ Knowing, as I know, that in this life Everything is crying, sadness and bitterness,

And that there isn't even one creature

That doesn't regret a lost illusion.

Knowing that the fancied happiness

Is shadow, and no more than an imposture,

And that the only sure aspiration

Is that which invites us to eternal sleep:

My voice can't raise its accent

To wish you, adding to those you possess,

Other years of struggle and suffering;

But my voice gives its congratulations to you,

Because I know that until the last moment,

Honesty will shine on your temples.

But the best proof of the singular affection of the poet for his teacher was the last letter he left to Dr. Domínguez before taking his own life in the National School of Medicine housing for interns, where he entrusted him with two arduous missions: first, he told him that the poison he had ingested was potassium cyanide so that his corpse would not be autopsied: "make that my body is not torn into pieces", he asked with insinuating phrase; and second, he asked to apologize him before the school director, Dr. Rafael Lucio, for having taken that determination in the establishment ${ }^{12}$. His story as a prefect ends in 1877 , when he resigned to the job.

Going back to 1870 , we should mention that on that year, a competitive examination for forensic medicine professor. The examination was taken by doctors Agustín Andrade and Manuel Domínguez, who presented the thesis Alcoholism: history, causes, pathological and social effects and legal resources to prevent vice. Both were approved in the first voting, but in the second, Dr. Andrade had the majority of votes and earned the right to the teaching post. This didn't discourage Dr. Domínguez and on the next year, in 1871 , he took the open examination for teaching assistant for the therapeutics class, since Dr. Manuel Robredo had asked for license to leave the post for being seriously ill. He obtained the class having presented the thesis Calabar bean, and started working in January 1872. Three years later, on February 22, 1875, Dr. Robredo Died and, on behalf of Mr. Lerdo de Tejada government, he has then awarded the title of full professor of the course. On that same year, the government of the Federal District appointed him vaccine propagator in the city and its surroundings. In March 1877 he obtained by competition the post of syphilographist physician at the San Andrés Hospital. $\mathrm{He}$ attended the Medical Congress celebrated in Rome in 1894 as delegate of our country, and in November 1902 he took charge of the direction of the School of Medicine in the absence of Dr. Ediardo Liceaga ${ }^{3,13,14}$.

\section{Political activities and public service during the Porfiriato}

His participation in Maximilian imperialist government did not exclude Dr. Domínguez from occupying different publicly-elected posts during the Porfiriato, since he was councilor, governor, congressman and senator of the republic. On his first political activity in that period, Dr. Domínguez participated, and apparently won, in the 1878 elections for Querétaro third district congressman; however, in a public letter addressed to his electors, he pointed at an alleged fraud to favor Hilarión Frías. In that document he expressed his gratitude and trust to the people of San Juan del Río for spontaneously and unanimously having deigned him as their representative in the $9^{\text {th }}$ Constitutional Congress ${ }^{15}$. He was not congressman on that term, but that same year, he was elected councilor of the Federal District, a post he occupied on several occasions (1879, 1880, 1885, 1886 and 1893), being city council president in 1880 and 1893; in addition, in the latter year he occupied the post of governor of the Distrito Federal in substitution of General José Ceballos, who had passed away. He was also congressman in the $17^{\text {th }}$ and $18^{\text {th }}$ terms of the Congress of the Union, substitute senator for the Distrito Federal in 1886 and senator for the State of Zacatecas for the 1906 to 1910 period $^{2,3,14}$.

\section{Groups and medical societies}

He was member of Liceo Hidalgo, the Mexican Society of Geography and Statistics, the Catholic Society of Mexico and the Society of Natural History; president of the Philoiatric and Assistance Society of the School of Medicine students; the Medical Society of Guanajuato; honorary member of the Great Circle of Workers and of the Mexican Dental Association; corresponding member of the Medical-Pharmaceutical 
Society of Yucatán; collaborator of the Medical Society of Guadalajara; and honorary member and chairman of the National Academy of Medicine in 1886. In particular, it should be noted that, at the behest of Dr. Domínguez, on May 12, 1867, the Medical Weekly Society was created, which was a scientific, charitable and recreational group that brought his colleagues doctors Francisco Brasseti, Manuel Carmona, José María Bandera, Eduardo Liceaga and Juan María Rodríguez together, with the purpose to form a group of brothers that consulted the difficulties occurring in their practice, periodically offer each other distraction and relaxation at their homes, and to help each other with the difficulties of life; later, the group changed its name to Family Society of Medicine ${ }^{3,12,16}$.

\section{His participation in the National Academy of Medicine}

Dr. Manuel Domínguez joined the National Academy of Medicine on May 13,1868, he was recognized as honorary member on March 7, 1885, and soon after he was elected chairman of the corporation for the 1886-1887 period. He wrote several works for Gaceta Médica de México; for example "Memory on human vaccine innocuousness", "Puerperal fever", "Compounded prescriptions", "Brief reflections about the way to prescribe in Mexico", "Tuberculosis, autopsy of a subject who died from this disease", "Reflections on a diagnostic error in a case of pregnancy", "Jaborandi", "On apomorphine", "On measles", "Some reflections on eserine physiological action, "Brief reflections on oxygen therapeutic administration", "Urethral narrowing", "Peritonitis", "Urethrotomy" and "On tartar"17. However, perhaps his most widely known participation was the defense he made within the Academy on the innocuousness and safety of vaccines, which Dr. Domínguez himself described as follows: "In the year of 1868, in the National Academy of Medicine, there was a vibrant discussion with regard to vaccination, which was named degenerate and it was accused that with it and through it, if it carried blood of the vaccinifer, it would or could penetrate the repugnant syphilitic virus in the clean bodies of children; being, therefore, mandatory abandoning and substituting it with the lymph of vaccinated calves. Such an unfair accusation alarmed the public, and the Academy was erected as the Grand Jury to judge the defendant. The accusation was mainly upheld by doctors Iglesias and Carmona, with the advocates being the similarly graduates Andrade, Rodríguez and Reyes. For my part, still feeling small in the face of the combatants on scientific contest, felt obliged to raise my voice in defense of the inestimable treasure trusted in our hands by God against devastating smallpox. I acted like this because, having been official vaccinator for several years, there were more than 20,000 vaccinated subjects by my own hand recorded in the notes I keep; even when sometimes I took bloody lymph with the needle, I argued that red blood cells are not syphilis vectors accidentally taken when injuring the vaccine blister; to prove my claim, I offered to suffer the inoculation of blood of a syphilitic individual in my own person. Having accepted the offering, it was duly acknowledged to the point of persuasion that my body was free of any trace of past syphilitic or venereal infection; and in a given day, I was brought to the San Lázaro city gate, where a syphilitic individual with second-stage disease was an employee and who accepted to participate in the experiment. From the skin of this person, and from the areas free of the pustular, scabby eruption that almost covered it, blood was taken with the needle and then inoculated in me, up to eight punctures in the arms; of note, the tenacity of Carmona to make sure that the device was well loaded with the fluid I was being inoculated was noticeable. The Academy was informed of the result of the experiment, which, to my fortune, was negative"4.

Another important anecdote related to this discussion is narrated by Dr. Luis Hidalgo y Carpio, editor of Gaceta Médica de México in an editorial note preceding the speech entitled "Can human vaccine be a vehicle for syphilis?", delivered on September 2, 1868 by Dr. Domínguez before the Medical Society of Mexico (previous denomination of the Academy), where we can read the following: "The speech was not initially published in the Gaceta because the section of the Academy in charge of the editorial office thought at that moment it was convenient to refrain from bringing it to the light, since that experiment exposed the lightness L'Académie Impériale de Médecine of Paris accepted the facts of vaccinal syphilis with, which Mr. Depaul adduced as proof of its existence. As we have read in several letters written by Mexican professors, doctors Rayón, Andrade and Muñoz (D. Miguel), who currently reside in Paris, and who attended the session the famous Académie Impériale celebrated on the afternoon of June 29, 1869, when Mr. Jules Guérin defended again the human vaccine, adducing new proofs and making use basically of the same arguments used by its defenders in Mexico, Misters Muñoz (D. Luis), Domínguez, Reyes (D. José María), 
Lavista, Menocal and Andrade. It should be noted that the fairly renowned editor of the Paris Medical Journal had received some time before all manuscripts on vaccines that had been published here, sent by our countryman Mr. Andrade. Anyway, Mr. Guérin has not had the delicacy, at least to this day, of citing the Mexican physicians who defended the human vaccine, in spite of having used their arguments and their works. This is why we have thought it is only fair publishing this speech, at least to leave proof that the arguments and facts on which the defenders of the calf vaccine wanted to lean on, both in Europe and America, were refuted in the Mexican Academy of Medicine before than in the Paris Academy or any other. It is a simple issue of priority, which we defend, because we have the original documented works, for national honor and other particular causes that would be idle to refer to." 18,19 .

During his term as chairman of the Academy, worried about child mortality, he published an invitation to a contest named "Which are the causes that originate the diseases that in Mexico City produce such a high mortality in early childhood, and which are the appropriate remedies to fight them?", which should be formulated in clear precepts and in the form of a booklet, accessible to the common people. Two proposals were received in closed envelopes, one with the epigraph "Booklet that can serve to remedy children's mortality in Mexico" and the second with the title "Felix qui potuit rerum cognocer e causas"; however, the qualifier jury, comprised by doctors Agustín Reyes, Domingo Orvañanos, Demetrio Mejía and Luis E. Ruiz, considered that neither of the proposals deserved the prize, and thiu they were filed and not published ${ }^{20}$.

\section{National School for Blind People}

The National School for Blind People was founded on March 1870 by Mr. Ignacio Trigueros in a few classrooms of the old Colegio de San Gregorio, provided by D. José M. Zayas. Subsequently, on May 1871, Benito Juárez government handed over to the school part of the old La Enseñanza convent, which was then reserved for State prison, where Dr. Domínguez never was brought as a prisoner to thanks to Minister Lerdo de Tejada. The school was directed by its founder until January 22, 1877, and then by Don Antonio Martínez de Castro until August 2, 1878, when the direction was assumed by Dr. Manuel Domínguez, who in those days was one of the councilors of the municipal corporation, and under his governance, the school reached a degree of prosperity that placed it at the level if similar establishments of its class in Europe ${ }^{21,22}$. Dr. Domínguez distributed the tasks of the students in such a way that, with no fatigue, they were able to develop both their intelligence and their knowledge on some trade, as well as their musical learning. This allowed, among other things, that the school orchestra offered concerts in different cities of the country, such as Orizaba and Toluca, where they were enthusiastically applauded. It should also be mentioned that, during his administration, the students received numerous diplomas and medals for the presentation of their works in different exhibitions attended by them with their works, which could be appreciated in the school walls; there were the inappreciable documents whereby the qualifying committees of Amsterdam, Mexico, Veracruz, Toluca and Querétaro, among others, had honored the students for their artworks in trimming, rush mats, woven liana, brush making, impression in dots and enhanced letters, needle knitting, etc. ${ }^{21,22}$. We should also mention that, guided by his medical training, Dr. Domínguez embarked on the task of documenting the causes of blindness in children arriving to the school, with the most important being smallpox, neonatal conjunctivitis, fundus lesions, ulcerative keratitis (scrofulous), staphyloma, consequence of an unfortunate operation and facial burns, which he published in a brochure entitled Brief history of the National School for Blind People ${ }^{21}$.

\section{The Foundling House (La Cuna)}

Dr. Nicolás de León refers that Dr. Domínguez handed him over an unpublished manuscript narrating the history of the Foundling House, also known as La Cuna, and published it in his book Obstetrics in Mexico in 1910. There, the following can be read: "By supreme orders, on January 18, 1898, I handed over the direction of the School for Blind People to Mr. Don Juan Ramírez de Arellano, passing that same day to the Foundling House to take care of its direction, which was handed me over by Dr. Ángel Carpio. Not without some sorrow, I must confess, I left an establishment that I led for 20 years, dedicating all my energy to the benefit of the unfortunate class of its inmates. However, my sorrow was very much attenuated by the consideration that if that school, the one for blind people, is highly interesting for its highly noble purpose, not less it is an establishment that receives in its bosom children who arrive to the world 
without being received by the holy parental love, or for special circumstances where this natural affection cannot shelter them with its sweet shadow" .

Dr. Domínguez was in charge of such a beneficial house until October 2, 1905, when, due to intrigue, as referred by Dr. Javier Carrillo in his work entitled " $\mathrm{La}$ cuna: it past, its present and its future", he resigned from his position as director, with Dr. Francisco de $\mathrm{O}$. Carral entering in his place ${ }^{23}$. Since his arrival to $L a$ Cuna, Dr. Manuel Domínguez he was devoted with great determination to accomplish his mission by carrying out very important reforms, especially in the care of the inmates. He is responsible for the creation of a set of "Foundling House Regulations", which included the "Nursemaid inspection" regulations, where he showed his concern for the nutrition and health care of the infants and the nursemaids that fed them. This set of rules was approved by the Ministry of Internal Affairs in 1898, and there we can see that there were three types of inmate children: foundlings, abandoned children, father- and motherless children without a relative or person who wanted to pick them up, and were La Cuna's legitimate children; sheltered children, who could not be supported and educated by their parents due to the lack of resources; and boarder children, who for a monthly fee, were brought to the house by their parents or relatives. There it is also stated that children were admitted since birth and until 4 years of age, regardless of gender, and boys could stay until 10 years of age and girls until 21 years ${ }^{5}$.

Chapter I of the regulations is dedicated to the care of children, and it establishes that the rectoress should receive children who were referred demanding asylum, regardless of the hour of day or night, and the age of the child and its conditions upon arrival had to be recorded. Having understood the difficulties there were to identify the children, Dr. Domínguez thought it would be convenient that, once admitted, the doctor of the house should methodically record the children's biometric and anthropometric data, so that each child had to be weighted, measured and written down in a special book under progressive numeration, stating the date of reception, the child's name (if he/she had one), particular signs, and any data that could serve to easily identify the child ${ }^{1,5}$.

As indicated by the regulations, some would stay in the hose and some would be sent to the country, under the care of nursemaids whose health and good behavior would be respectively confirmed by the doctor and the political authority of the place the woman resided. Any child sent to the country that would get sick, would be brought to the house for care, and if unfortunately the child did arrive dead, and the explanation of this fact was not satisfactory, the director should remand the child's corpse and the nursemaid to the relevant authority, to find out if there was any crime requiring a penalty. Children sent to the country would also be sent back to the house at the age of weaning, with nursemaids of the country being forced to come to the house every 15 days with the children they were entrusted with, in order for the director, accompanied by the nursemaid inspector physician, to examine the nursemaids and children. Any child who in the inspector physician's opinion was not in good conditions, would receive a different nursemaid or stay in the house, according to what the physician considered convenient ${ }^{5}$. These regulations were very important since, until then, children were brought to the country, where they were entrusted to a woman who acted as a nursemaid and fed the child without prior medical examination, without knowing the quality of her milk, and that might feed the child on corn flour drink (atole) and even tortillas and beans, all this under direct supervision of a woman that, owing to a never disproven honesty, was regarded as a guarantor. During their permanence in the country, these poor children lived together with the nursemaids in the humblest shacks, exposed to the rigor of elements and fed the way the nursemaid found best, which made for them to often get sick and, most unfortunate, to lose their lives ${ }^{23}$.

According to Dr. Domínguez regulations, inmate boys and girls in the house were grouped in three sections: infants, 2 to 5 years, and older than 5 years; the first two had mixed halls, and the third one had halls divided be gender. Each infant had a nursemaid assigned, who was under continuous supervision by a wardress and the rectoress, with regard to her behavior, her tidiness and to the treatment given to the child they were nursing. Every month, the inspector physician had to practice an examination of the house nursemaids, in order to verify their health and quantity and quality of their milk. In addition, he had to monitor the children's growth, especially when any of them was observed to be failing to thrive. Boys and girls of 2 to 5 years of age, were under the care of young daughters of the house appointed by Dr. Domínguez; there was one for every 10 children, with all of them being guided and trained by a wardress, also a daughter of the house. In turn, the director had among his obligations taking care that the children were timely vaccinated, prevent that employees would impose 
punishments to the children causing physical pain or embarrassment, and authorize the marriage of young foundling girls provided, in his opinion, the wedding was favorable to the future of the young girl ${ }^{5}$.

In the nursery, the nursemaid wardress had to watch that they would treat the children they breastfed well, that they bathed then every other day, that they kept them constantly clean, by washing their clothes as often as necessary, and that the cradles were free of filth and insects. In turn, the house physician had the obligation to pay a visit every day in the morning, even if no children were sick, and in the afternoon or night when he deemed it necessary if a child was seriously ill ${ }^{5}$.

The nursemaid inspection regulations refer to a nursemaid dispensary, which was also approved by the Ministry of Internal Affairs by the end of 1898, and had the purpose to provide nursemaids to people requesting them; a real public benefit, because since some time ago, randomly obtained nursemaids had been observed to be sick or have poor quality milk, both these things with terrible results for children. The first inspector physician was Dr. Miguel Márquez, who had the duty to attend the office every day, receive al nursemaids filing a request for destination, examining then and writing down ion his book the name of the nursemaid, her age, her address, the date she had given birth, the form of the breasts and nipples, the state of her digestive, circulatory, respiratory, nervous and urogenital systems, signs of previous diseases or tracks of generalized diseases and, especially, analysis of her milk, including its color, abundance, reaction, density, richness in butter, sugar, albuminoids, etc., as well as microscopic characters of figures elements. The place of residence, people who vouched for her behavior and the child the nursemaid was entrusted with was written down in a special nurse registry $^{5}$. Soon after having arrived to La Cuna, Dr. Domínguez requested from the Civil Registry judges that, when registering inmate children that had no family name to assign them the family name Lorenzana, who was the honorable founder of this almshouse. Soon after, on June 9, 1899, the nursemaids' inspector proposed for the vaccine to be administered in the establishment under direct supervision of the Public Health Superior Council, which was approved the $29^{\text {th }}$ of that montn ${ }^{5,23}$.

Owing to the lack of nursemaids, trying artificial breastfeeding with cow milk mixed with some plant infusions was proposed in November 1898. The experiment was carried out in 20 children under the direction of rectoress Mrs. María B, Vda, de Escalante, but the test did not yield satisfactory results. On October 5 , 1899, a new element joined to collaborate with Dr. Domínguez, Dr. Ricardo E. Cicero, who helped the director on his task of reorganizing the infirmary and the medicine cabinet, keeping an adequate log on general movements of inmates' admission and discharge, writing down the aforementioned data for identification, and acquiring in those days a model Tarnier incubator to save the lives of many premature children or children with congenital weaknes ${ }^{23}$.

There is an anecdote from those days, referred by Dr. Cicero, who wrote: "Dr. Domínguez insisted very much on improving the care required by the Casa Cuna children, and hence he implemented a medical service as complete as possible and he got nurses and a medicine cabinet. However, in those days there was a bad habit, which was tried to be fought immediately: naughty children were threatened with calling the doctor to prescribe them a purgative, so that inmates were afraid of the doctor. Work was done to eradicate this fear by treating the children with affection and making then understand that the doctor was their friend. Mortality had also been observed to be high, especially associated with infectious diseases, mainly measles, with its terrible respiratory complications, and an isolation room was therefore been made available, but in spite of this good precaution, danger could not be eliminated owing to the special nature of the disease, which was contagious since the first days" 24 .

In 1904, Dr. Cicero resigned to the post of establishment physician, and was officially replaced by Dr. Rafael Carrillo on February 16 of the same year, who collaborated with Dr. Domínguez in La Cuna reforms, including the creation of an intern post and the establishment of printed forms containing all indispensable data to appreciate the children's status of health and disease (weight, height, nutrition, temperature, etc.). In order to look for a solution to the artificial nutrition problem, since the shortage of nursemaids continued, Dr. Carrillo decided to repeat the artificial nutrition assay, since the one in 1898 had been insufficient. On July 1904, encouraged by Dr. José Terrés, a highly renowned clinician and one of the main promoters of artificial nutrition, which he already practiced with great success with his private customers, and by Dr. Aniceto Ortega, who had implemented an autoclave-sterilized milk, decided to carry out the experiment. Aided by the rectoress, Mrs. Luz González Cosío de López and by Nursing School personnel, the experiment was carried out. The experience demonstrated that milk sterilized 
by ebullition (Soxlet procedure) and in autoclave, exclusively administered in the nutrition of children younger than 1 year, was unable to substitute the natural product, since most of the 30 undergoing the experimental diet died from diarrhea or inanition, unable to assimilate the foods. This failure of artificial nutrition confirmed that breast milk was superior for children's nutrition and survival23-25. During his administration, from 1898 to 1905 , the movement of children was one of the most numerous La Cuna ever had, since in that period, 1598 children were admitted, only in 1903, 454 children were admitted, out of whom 382 were younger than 1 year of age. However, mortality was elevated $(41.23 \%)^{23}$.

\section{The end of his fruitful life}

Dr. Manuel Justo Domínguez Quintanar (Fig. 1), virtuous gentleman, illustrious physician and notable man of letters, succumbed victim of the white plague (tuberculosis) on March 16, 1910, at nearly 80 years of age ${ }^{5}$. His life advanced with the development of history: he was born in the era of the first Federal Republic, he graduated as a physician during Antonio López de Santa Anna dictatorship, he developed his assistance and political activity during the reform, the French invasion, the second Mexican empire, the restored republic and, of course, the Porfiriato, and died a few months before the revolutionary explosion that would completely change Mexico's political and social panorama.

\section{Corollary: childcare and technical pediatrics}

In spite of the knowledge about children's diseases, the practice of the art by the end of the $19^{\text {th }}$ century was carried out in trial conditions and within the darkness of childhood phenomena. However, according to Dr. Rafael Carrillo, Dr. Domínguez work was highly altruist and intense, and he was responsible for taking the first steps towards founding a rational childcare school, a situation recognized and supported by Professor Dr. Alfonso G. Alarcón, who points that it was his sagacious spirit that allowed for him to create in 1900 technical pediatrics in Mexico ${ }^{2,23}$. The role of the Foundling Home in the regulation of nurse maids and its innovations in children's nutrition laid the foundations of our national childcare and established a prototype for health and the programs of public wellbeing, which emerged after the revolution. The physicians who administered the children's nutrition programs at the Foundling House (La Cuna) emerged

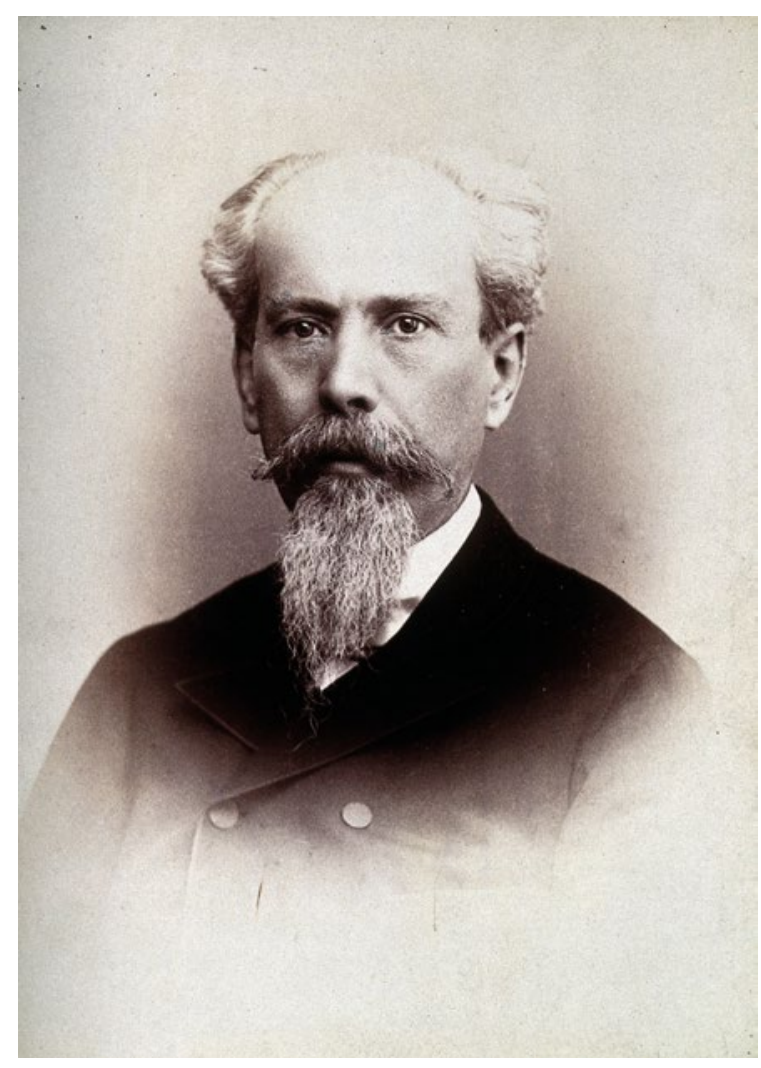

Figure 1. Dr. Manuel Justo Domínguez Quntanar (photograph of Cruces y Cía. Wellcome Collection).

as the leaders of Mexican childcare after the war. The loss of population during the revolution made for the project of mortality reduction to be a national priority. The public health programs started early in the decade of 1920 reflected the influence of childcare on the wellbeing of Mexican children. Childcare offered then a scientific approach to the health and development of the child from conception to puberty, tightly linked to maternal health care, to a hygienic environment in the household and to the places where the child spent part of the time $^{25,26}$.

\section{References}

1. Alarcón AG. La aportación de los médicos mexicanos a la pediatría. Gac Med Mex. 1944;74:323-43.

2. León N. La obstetricia en México. México: Tip. de la Vda. de F. Díaz de León, Sucrs.; 1910.

3. Anónimo. Biografía del autor. En: Domínguez M. Obras (leyendas históricas). México: Imp. de V. Aguepos; 1909. p. V-XVI.

4. Domínguez M. Discurso pronunciado por el Dr. Manuel Domínguez en la ceremonia de la inauguración del monumento al Dr. Manuel Carmona y Valle. En: Domínguez M. Obras (leyendas históricas). México: Imp. de V. Aguepos; 1909. p. 421-44.

5. López de Santa-Anna A. Decreto del gobierno. Plan general de estudios de la República mexicana. En: Dublan M, Lozano M, editores. Legislación mexicana o edición completa de las disposiciones legislativa expedidas desde la Independencia de la República. Tomo IV. México: Imprenta del Comercio, a cargo de Dublan y Lozano, hijos; 1876. p. 514-23.

6. Ocaranza F. Historia de la medicina en México. París: Drager; 1934. p. $155-7$. 
7. Cano-Sordo V. De la Luisiana a la Nueva España. La historia de Juan Bernardo Domínguez y Gálvez (1783-1847). México, D.F.: Impresora Múltiple; 1999.

8. Ratz K, Gómez-Tepexicuapan A. Los viajes de Maximiliano en México (1864-1867). México, D.F.: CONACULTA; 2012.

9. Anónimo. Anuario de las Ordenes Imperiales. México: Imprenta de J. M. Lara; 1865. p. 13.

10. Fajardo-Ortiz G. Una investigación acerca del historial médico durante el sitio de Querétaro, 1867. Gac Med Mex. 1997;133:35-9.

11. Acuña M. Obras. Barcelona: Tip. Casa Editorial Sopena; 1873. p. 109.

12. Caffarel-Peralta R. El verdadero Manuel Acuña. México: UNAM; 1999.

13. León N. Biblioteca Botánico-Mexicana. México: Oficina Tip. de la Secretaría de Fomento; 1895. p. 109.

14. El Heraldo. El Sr. Dr. D. Manuel Domínguez. Gac Med Mex. 1910;5:I-IV.

15. Domínguez M. Carta abierta a mis electores. De México a San Juan de Río. 28 de agosto de 1878.

16. Flores FA. Historia de la Medicina en México, desde la época de los indios hasta la presente. Tomo III. México: Oficina Tip. de la Oficina de Fomento; 1888

17. Cárdenas-de la Peña E. Médicos mexicanos. El doctor Manuel Domínguez, ilustre médico queretano. Bol Mex His Fil Med. 2000;3:33-9.
18. Los redactores. A nuestros suscriptores. Gac Med Mex. 1869;4:255-6.

19. Domínguez M. ¿La vacuna humana puede ser vehículo para la sífilis? Gac Med Mex. 1869;4:256-67, 271-8.

20. Cordero M. Sesión del 27 de octubre de 1887. Acta Núm. 5, aprobada el 9 de noviembre. Presidencia del Sr. Dr. Bandera. Gac Med Mex. 1887;22:531-3.

21. Domínguez M. Breve historia de la Escuela Nacional de Ciegos. México: Oficina Tip. de la Secretaría de Fomento; 1889

22. Rivera-Cambas M. México pintoresco, artístico y monumental. Tomo segundo. Escuela Nacional de Ciegos. México: Imprenta de la Reforma; 1882. p. 120-6

23. Carrillo R. La Cuna; su pasado, su presente, su porvenir. Gac Med Mex. 1915;10:320-44.

24. Cicero R. Acta número 13. La Casa de Cuna. Gac Med Mex. 1915; 10:565-6.

25. Carrillo R. Gestación: la puericultura en México. Rev Mex Pediatr. 2005; 72:94-6.

26. Blum AS. Domestic economies. Family, work, and wellfare in Mexico City, 1884-1943. Nebraska: University of Nebraska Press; 2009. p. 71-102. 